\title{
KADAR FENOLIK DAN AKTIVITAS ANTIOKSIDAN EKSTRAK ETANOL RUMPUT LAUT COKLAT (Padina australis)
}

\author{
Tri Saptari $\mathrm{H}^{1}$., Triastinurmiatiningsih ${ }^{1}$, Bina Lohita $\mathrm{S}^{2}$., Indah Nur Sayyidah ${ }^{1}$ \\ ${ }^{1}$ Program Studi Biologi FMIPA Universitas Pakuan. \\ ${ }^{2}$ Program Studi Farmasi FMIPA Universitas Pakuan. \\ Email: trisaptari@unpak.ac.id
}

\begin{abstract}
ABSTRAK
Rumput laut coklat Padina australis merupakan salah satu sumber daya alam laut yang keberadaannya sangat melimpah di perairan pantai Bayah, Banten Indonesia. Kandungan senyawa fenolik dan turunannya (flavonoid) berhubungan dengan aktivitasnya sebagai antibakteri dan antioksidan. Fenolik dianggap sebagai molekul dengan potensi tertinggi untuk menetralkan radikal bebas. Penelitian ini bertujuan untuk menentukan kadar fenolik dan aktivitas antioksidan ekstrak etanol $P$. australis menggunakan pereaksi Follin-ciocalteu dan 1,1-diphenyl-2-picryl hydrazyl (DPPH) ekstrak etanol $P$. australis. Hasil penelitian menunjukkan kadar fenolik sebesar 42,62 mg SAG/g serbuk dan pada konsentrasi 5000 ppm menghambat sebesar 66, $01 \%$ radikal bebas DPPH.
\end{abstract}

Kata kunci: Padina australis, kadar fenolik, aktivitas antioksidan, Follin-ciocalteu, $\mathrm{DPPH}$

\section{PHENOLIC CONTENT AND ANTIOXIDANT ACTIVITY OF Padina australis BROWN SEAWEED ETHANOL EXTRACT ABSTRACT}

Padina australis brown seaweed is one of marine natural resources which is abundant in the Bayah coastal waters, Banten Indonesia. The chemical content of phenolic and its derivatives (flavonoid) of this seaweed are associated with their activities as antibacterial and antioxidant. Phenolics are regarded as the molecules with the highest potential to neutralize free radicals. This study was carried out to determine the phenolic content and antioxidant activity of $P$. australis extract use Follin-ciocalteu and 1,1diphenyl-2-picryl hydrazyl (DPPH) reagent. The result of phenolic content was 42.62 $\mathrm{mg} \mathrm{GAE}$ and at $5000 \mathrm{ppm}$ concentrations it inhibit $66.01 \% \mathrm{DPPH}$ free radicals.

Keywords : Padina australis, phenolic content, antioxidant activity, Follin-ciocalteu, DPPH

\section{PENDAHULUAN}

Rumput laut (seaweed) merupakan salah satu sumber daya hayati yang sangat melimpah di perairan Indonesia yaitu sekitar 8,6\% dari total biota di laut (Dahuri, 1998). Rumput laut coklat mengandung senyawa aktif yang dapat berfungsi sebagai antioksidan alami diantaranya phlorotannin dari golongan fenol dan pigmen fucoxanthin serta xantofil (Peng et al., 2011). Padina australis merupakan salah satu rumput laut coklat yang memiliki bentuk lembaran atau filamen yang lebar 
berwarna cokelat transparan (Kemenangan et al., 2017). Penelitian $P$. australis yang pernah diteliti antara lain aktivitas antibakteri ekstrak etanol terhadap Staphylococcus aureus, Streptococcus pneumoniae, Escherichia coli dan Neisseria gonorrhoeae. Aktivitas antioksidan ekstrak dinyatakan aktif dengan dekolorisasi larutan metanol-DPPH (Hongayo et al., 2012).

Penelitian Haryani et al., (2008) menunjukkan bahwa $P$. australis dapat menghambat pertumbuhan bakteri E. coli. Hambatan terhadap pertumbuhan bakteri karena ekstrak etanol mengandung senyawa terpenoid, steroid, alkaloid dan fenolik. Senyawa fenolik merupakan molekul yang dapat bertindak sebagai antioksidan untuk mencegah penyakit jantung, anti radang, anti kanker dan antidiabetes, dan antimutagenesis. Penggunaan makanan dari produk tanaman seperti buah-buahan, sayuran dan kacang-kacangan sebagian besar terkait dengan adanya senyawa fenolik pada tanaman tersebut (Khoddami et al., 2013). Senyawa fenolik memiliki cincin aromatik dengan satu atau lebih gugus hidroksi (OH-) dan gugus-gugus lain penyertanya. Senyawa ini diberi nama berdasarkan nama senyawa induknya yaitu fenol. Senyawa fenol kebanyakan memiliki gugus hidroksi lebih dari satu sehingga disebut sebagai polifenol. Beberapa senyawa yang termasuk dalam kelompok fenolik adalah fenol sederhana, polifenol, kumarin, tannin, saponin, dan flavonoid. Senyawa tersebut biasanya berada dalam bentuk glikosida atau ester pada tanaman (Proestos et al., 2006).

Salah satu analisis penentuan kadar fenolik menggunakan pereaksi FolinCiocalteu (FC). Reaksi kolorimetri yang digunakan pada analisis dengan pereaksi FC menggunakan senyawa standar, kemudian diukur konsentrasi total gugus hidroksi fenolik pada ekstrak tanaman.
Polifenol dalam ekstrak tanaman bereaksi dengan pereaksi FC membentuk kompleks dari kromofor membentuk kompleks fosfotungstatfosfomolibdenum berwarna biru. Absorpsi maksimum berhubungan dengan larutan basa dan konsentrasi senyawa fenolik (Bralainski et al. 2013). Metode FC ini mudah, sederhana, menggunakan peralatan yang umum digunakan dan memberikan hasil data yang berkorelasi antara nilai di dalam satu sampel (Pelozo et al., 2008).

Efek berbahaya dari radikal bebas menyebabkan potensi kerusakan biologis (oxidative stress) sehingga dapat merusak jaringan lipid, protein atau DNA seluler dan menimbulkan sejumlah penyakit pada manusia serta dalam proses penuaan (Valko et al., 2006). Menurut Halliwell dan Gutteridge (2000) antioksidan merupakan senyawa yang dapat menghambat spesies oksigen reaktif/spesies nitrogen aktif (ROS/RNS) dan juga radikal bebas sehingga dapat mencegah penyakit-penyakit yang dihubungkan dengan radikal bebas seperti karsinogenesis, kardiovaskular dan penuaan dini. Beberapa penelitian menunjukkan penggunaan DPPH untuk metode penangkal radikal mempunyai keuntungan yaitu mudah digunakan, tingkat sensitivitas tinggi, dan dapat menganalisis sejumlah besar sampel dalam jangka waktu yang singkat (Kim et al., 2002). DPPH merupakan radikal yang stabil dan digunakan untuk menskrining beberapa senyawa metabolit sekunder seperti dibawah ini (Gambar 1).

\section{METODE PENELITIAN \\ Waktu dan Tempat}

Penelitian ini dilaksanakan pada bulan Mei - Juli 2017 di Laboratorium Biologi, Laboratorium Farmasi dan Laboratorium Kimia FMIPA Universitas Pakuan. 


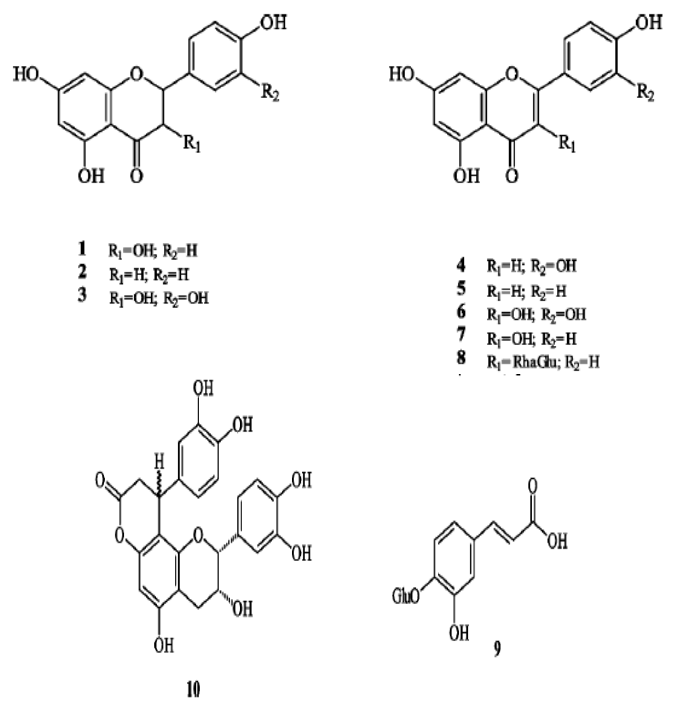

Gambar 1. Struktur kimia senyawa fenoli 1-10 (Brighente et al., 2007)

\section{Alat dan Bahan}

Alat yang digunakan dalam penelitian ini, antara lain, kertas saring, corong, botol gelap, rotary evavorator, cawan uap, timbangan analitik, grinder, alat-alat gelas, moisture balance dan spektrofotometer UV-Vis .

Bahan-bahan yang digunakan pada penelitian ini yaitu rumput laut $P$. australis dari perairan Pantai Bayah (Banten), etanol 96\%, asam galat, $\mathrm{Na}_{2} \mathrm{CO}_{3}$ $7,5 \%$, asam askorbat, metanol, pereaksi Follin-Ciocalteu dan DPPH. Bahan kimia diperoleh dari Sigma-Aldrich .

\section{Pembuatan Simplisia Padina australis}

$P$. australis yang telah dicuci bersih, ditiriskan untuk membebaskan sisa-sisa air cucian, kemudian diangin-anginkan. Kemudian dikeringkan dalam oven pada suhu $50^{\circ} \mathrm{C}$. Dihaluskan menggunakan alat (grinder) hingga menjadi serbuk. Diperoleh simplisia kering. Susut pengeringan dihitung dengan rumus:

$$
\text { Susut pengeringan }=\frac{\text { Berat awal }- \text { Berat akhir }}{\text { Berat awal }} \times 100 \%
$$

\section{Penetapan Kadar Air}

Penetapan kadar air simplisia dilakukan dengan menggunakan alat moisture balance dengan menimbang kurang lebih satu gram serbuk simplisia (DepKes RI, 1979).

\section{Pembuatan Ekstrak Padina australis (Depkes, 1995)}

Ditimbang $150 \mathrm{~g}$ serbuk simplisia kemudian dimaserasi menggunakan pelarut etanol $96 \%$ sebanyak 3,5 L hingga warna konstan dan dikocok selama 10 menit dalam rentang 1 jam selama 5 kali sehari, agar massa bioaktif dapat keluar dari thallusnya yang padat. Kemudian maserat disaring, diperoleh filtrat ekstrak cair etanol. Ekstrak cair di evaporasi menggunakan rotary evavorator pada suhu $45^{\circ} \mathrm{C}$ sampai dihasilkan ekstrak kental. Rendemen ekstrak dihitung dengan rumus :

$$
\text { Rendemen ekstrak }=\frac{\text { Berat ekstrak yang diperoleh }}{\text { Berat awal simplisia }} \times 100 \%
$$

\section{Pembuatan Larutan Induk Asam Galat 100 ppm}

Ditimbang $100 \mathrm{mg}$ asam galat dimasukkan kedalam labu ukur $100 \mathrm{~mL}$, kemudian dilarutkan dengan aquadest sampai tanda batas (1000 ppm). Untuk mendaptkan larutan induk asam galat dengan konsentrasi 100 ppm, dilakukan dengan cara memipet $10 \mathrm{~mL}$ asam galat (100 ppm), dimasukkan kedalam labu ukur $100 \mathrm{~mL}$ dan dilarutkan kedalam larutan aquadest sampai tanda batas. Ditentukan panjang gelombang maksimum dan waktu inkubasi optimum dari asam galat.

\section{Pembuatan Deret Standar Asam Galat}

Dibuat deret standar asam galat konsentrasi 1, 2, 3, 4 dan 5 ppm dari larutan induk asam galat $100 \mathrm{ppm}$ dengan cara dipipet masing-masing 0,$1 ; 0,2$ ; 0,3 ; 0,4 dan $0,5 \mathrm{~mL}$. kemudian masingmasing dimasukkan dalam labu ukur $10 \mathrm{~mL}$, ditambahkan $500 \mu \mathrm{L}$ pereaksi Follin-Ciocalteu lalu dikocok hingga homogen kemudian ditambahkan aquades 
hingga tanda batas dan dikocok hinga homogen.

\section{Penetapan Kadar Fenolik Total}

Penetapan kadar fenolik menggunakan metode Folin-Ciocalteu dengan modifikasi (Brighente et al., 2007). Pada penelitian ini, campuran reaksi terdiri dari $10 \mathrm{mg}$ ekstrak dalam 1,0 $\mathrm{L}$ aquadest, ditambahkan $500 \mu \mathrm{L}$ pereaksi Follin-Ciocalteu. Setelah dikocok homogen kemudian ditambahkan $4 \mathrm{~mL}$ $\mathrm{Na}_{2} \mathrm{CO}_{3} 7,5 \%$, dikocok selama 1 menit. Campuran diukur pada panjang gelombang maksimum dan diinkubasi pada waktu optimum (dilakukan penentuan sebelumnya). Kurva kalibrasi menggunakan asam galat $100 \mathrm{ppm}$, dan hasil dinyatakan dalam $\mathrm{g} / 100 \mathrm{~g}$ ekstrak $(\%)$.

Ditentukan kurva standar, regresi linier $\mathrm{y}=\mathrm{bx}+\mathrm{a}$ dibuat berdasarkan data absorbansi dan konsentrasi dari larutan standar, dimana:

$$
\begin{aligned}
& \mathrm{x}: \text { konsentrasi sampel }(\mathrm{mg} / \mathrm{L}) \\
& \mathrm{y}: \text { absorbansi sampel } \\
& \mathrm{b}: \text { intersept dari kurva standar } \\
& \mathrm{a}: \text { slope standar dari kurva standar }
\end{aligned}
$$

Kadar polifenol total dihitung menggunakan rumus berikut:

$$
\text { Kadar polifenol total }=\frac{\mathrm{Vs}(\mathrm{mL}) \times \mathrm{C}(\mathrm{ppm}) \times \mathrm{Fp} \times 10^{-6}}{\mathrm{~B}(\mathrm{~g})} \times 100 \%
$$

Keterangan:

Vs: Volume (mL)

C : Kadar total polifenol (ppm)

Fp : Faktor pengenceran

B : Bobot ekstrak yang digunakan (gram)

\section{Uji Aktivitas Antioksidan Metode DPPH}

Aktivitas antioksidan ekstrak $P$. australis ditentukan dengan metode Brand-Williams et al. (1995) dengan beberapa modifikasi. Sebanyak 10.000 ppm ekstrak etanol $P$. australis dibuat konsentrasi 312,$5 ; 625 ; 1250 ; 2500$; $5000 \mu \mathrm{l} / \mathrm{mL}$. Dipipet masing-masing $3 \mathrm{~mL}$ larutan ekstrak dan ditambahkan $1 \mathrm{~mL}$ larutan DPPH $1 \mathrm{mM}$ dalam metanol. Campuran dikocok dan didiamkan selama waktu optimum dan diukur pada panjang gelombang optimum. Digunakan larutan standar asam askorbat dengan deret larutan 0,$625 ; 1,25 ; 2,5 ; 5$ dan 10 $\mu \mathrm{L} / \mathrm{mL}$. Dipipet $3 \mathrm{~mL}$ masing-masing konsentrasi, ditambahkan $1 \mathrm{~mL}$ larutan DPPH $1 \mathrm{mM}$, kemudian ditambahkan metanol p.a sampai batas $(10 \mathrm{~mL})$, dan dihomogenkan selama waktu optimum pada suhu kamar. Nilai persentase hambatan terhadap DPPH dihitung menggunakan rumus berikut :

$\%$ inhibisi $=\frac{\text { Absorbansi blanko-Absorban sampel }}{\text { Absorbansi blanko }} \times 100 \%$

Nilai $\mathrm{IC}_{50}$ (Inhibition Concentration 50) diperoleh dari perpotongan garis antara $50 \%$ daya hambat dengan sumbu konsentrasi menggunakan persamaan linier $(y=b x+a)$, dimana $y=50$ dan $x$ menunjukkan $\mathrm{IC}_{50}$ (Windono et al., 2004).

$$
\mathrm{IC}_{50}=\frac{50 \text { - Intersept }}{\text { slope }}
$$

\section{HASIL DAN PEMBAHASAN \\ Serbuk Simplisia Padina autralis}

$P$. australis yang digunakan diperoleh dari pantai Bayah, Banten sebanyak $4600 \mathrm{~g}$ setelah melalui proses pembuatan serbuk simplisia dan diayak menggunakan mesh 40 diperoleh sebanyak $925 \mathrm{~g}$ dengan rendemen yaitu $80 \%$. Serbuk simplisia yang didapat berwarna kecoklatan serta memiliki bau yang khas (Gambar 2).

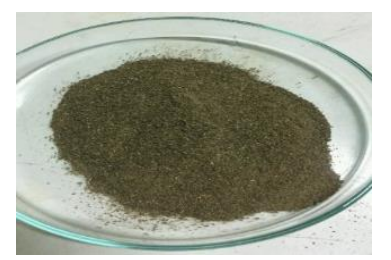

Gambar 2. Serbuk simplisia $P$. australis

\section{Analisis Karakteristik Simplisia Penetapan Kadar Air}


Penetapan kadar air berguna untuk memberikan batasan minimal atau rentang tentang besarnya kandungan air di dalam bahan. Penetapan kadar air dilakukan menggunakan alat moisture ballance. Semakin besar kadar air yang diperoleh maka semakin banyak pula mikroorganisme yang mungkin tumbuh dan akan meyebabkan kerusakan pada simplisia tersebut. Penghilangan kadar air hingga jumlah tertentu berguna untuk memperpanjang daya tahan simplisia selama proses penyimpanan (Depkes RI, 2000). Dari hasil penetapan kadar air serbuk simplisia $P$. australis didapatkan rata-rata sebesar $4,26 \%$, Hasil tersebut memenuhi syarat dimana syarat kadar air tidak lebih dari 10 \% (Depkes RI, 1995).

\section{Rendemen Ekstrak Padina australis}

Ekstrak $P$. australis didapat dengan cara ekstraksi menggunakan metode maserasi. Metode maserasi merupakan suatu metode pemisahan dengan cara penyarian yang sederhana dilakukan dengan cara merendam serbuk simplisia dalam cairan penyari. Maserasi bertujuan untuk menghindari terjadinya kerusakan terhadap komponen organik penyusun yang tidak tahan terhadap panas dan memudahkan penarikan senyawa kimia di dalamnya (Depkes RI, 2000). Serbuk simplisia awal $P$. australis yang digunakan sebanyak $150 \mathrm{~g}$ setelah melalui proses maserasi diperoleh ekstrak etanol sebanyak 5,22 g dengan rendemen ekstrak yaitu $3,48 \%$. Penentuan rendemen dimaksudkan untuk mengetahui perbandingan antara ekstrak yang diperoleh (jumlah hasil ekstrak) dengan simplisia awal (Depkes RI, 2000).

\section{Penetapan Kadar Fenolik Total}

\section{Penetapan Panjang Gelombang Maksimum}

Penentuan harus dilakukan pada panjang gelombang maksimum untuk mengetahui besarnya panjang gelombang yang diperlukan asam galat untuk mencapai serapan maksimum. Penentuan panjang gelombang dilakukan dengan menggunakan larutan asam galat sebagai standar analisis kuantitatif. Penentuan panjang gelombang maksimum dilakukan pada 650-800 $\mathrm{nm}$. Panjang gelombang yang didapat adalah 750m (Gambar 3).

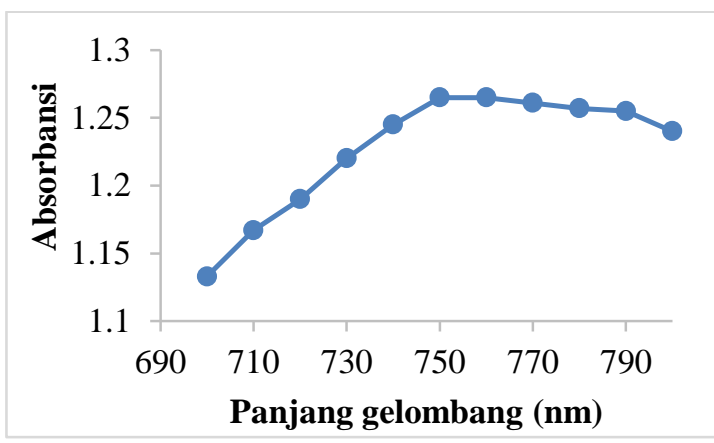

Gambar 3. Kurva panjang gelombang maksimum asam galat

\section{Hasil Optimasi Waktu Inkubasi}

Penentuan optimasi waktu inkubasi bertujuan untuk mengetahui waktu yang dibutuhkan suatu zat untuk bereaksi secara optimum sehingga menghasilkan serapan yang stabil. Waktu optimum yang dibutuhkan larutan asam galat pada panjang gelombang maksimum $750 \mathrm{~nm}$ yaitu menit ke-60 (Gambar 4).

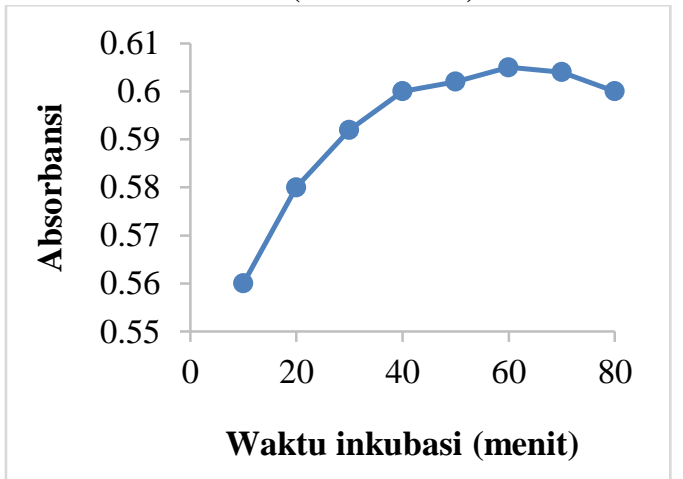

Gambar 4. Kurva optimasi waktu inkubasi asam galat

\section{Pengukuran Kurva Kalibrasi}

Kurva kalibrasi ditentukan untuk menghasilkan persamaan liniearitas antara absorbansi dengan konsentrasi dan menunjukkan besarnya konsentrasi larutan 
sampel dari hasil pengukuran. Konsentrasi sampel larutan dapat diperoleh dengan mudah melalui kurva standar asam galat dibuat kedalam beberapa deret konsentrasi antara lain 10 sampai 100 ppm. Persamaan yang didapat adalah $\mathrm{y}=$ $0,1492 x+0,0514$ dan nilai $R^{2}=0,9997$ yang artinya mendekati linearitas. Data lengkap hasil absorbansi pengukuran dapat dilihat Gambar 5.

\section{kurva kalibrasi}

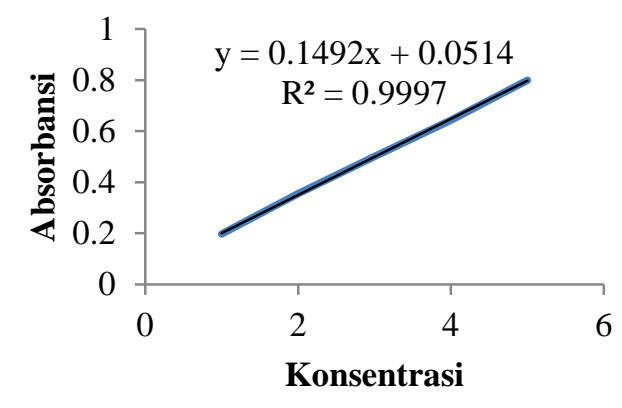

Gambar 5. Kurva Kalibrasi Standar Asam Galat

\section{Kadar Fenolik}

Kadar fenolik sampel dihitung melalui persamaan garis $\mathrm{y}=\mathrm{bx}+\mathrm{a}$ dengan nilai absorbansi sampel yang dihasilkan sebesar 0,115. Hasil penelitian menunjukkan bahwa ekstrak etanol $P$. australis memiliki kadar fenolik total sebesar 42,62 mg SAG/g serbuk.

Gugus aromatik pada senyawa fenolik menunjukkan kemampuannya sebagai antioksidan dan antimikroba yang dapat melindungi tubuh dari reaksi oksidasi dan sifat patogen. Radikal bebas dapat merusak sampai sel biomolekul seperti asam nukleat, protein, lipid dan karbohidrat, dan berkontribusi dalam stress oksidatif dan beberapa penyakit. Antioksidan dapat mengganggu produksi radikal bebas dan berperan untuk menonaktifkannya (Bajpai et al., 2005).

\section{Penetapan Panjang Gelombang Maksimum}

Tahap awal yang dilakukan pada penentuan aktivitas antioksidan ini adalah penetapan panjang gelombang maksimum larutan DPPH. Penetapan panjang gelombang maksimum ini bertujuan untuk mengetahui pada panjang gelombang larutan DPPH yang menghasilkan absorbansi maksimum pada spektrofotometer UV-Vis. Hal ini berkenaan dengan kepekaan analisis, dimana perubahan absorbansi untuk satuan konsentrasi adalah yang paling besar pada panjang gelombang maksimum sehingga akan diperoleh kepekaan analisis yang maksimum (Chow et al., 2003). Panjang gelombang maksimum yang didapat untuk pengujian antioksidan ini adalah $515 \mathrm{~nm}$ dengan absorbansi maksimum 0,843 .

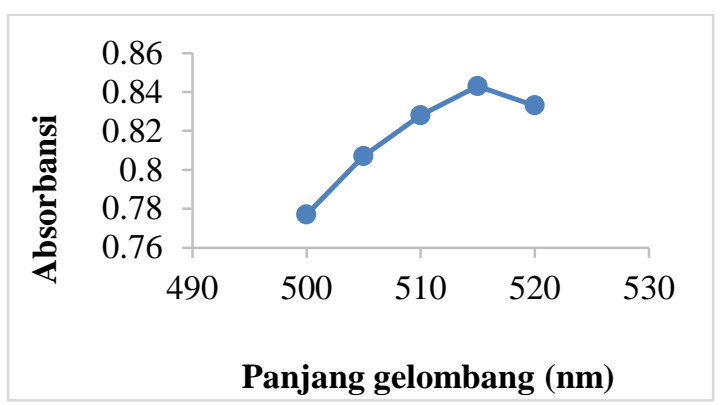

Gambar 6. Kurva Panjang Gelombang Maksimum DPPH

\section{Hasil Optimasi Waktu Inkubasi}

Penetapan waktu inkubasi optimum ditujukan untuk menentukan waktu penyimpanan yang memberikan serapan stabil atau waktu yang dibutuhkan oleh suatu zat agar dapat bereaksi secara maksimal. Waktu inkubasi optimum yang didapat pada menit ke- 30 (Gambar 7). Pengukuran aktivitas antioksidan ini menggunakan vitamin $\mathrm{C}$ (asam askorbat) sebagai standar. Asam askorbat merupakan salah satu antioksidan

\section{Penetapan Aktivitas Antioksidan}




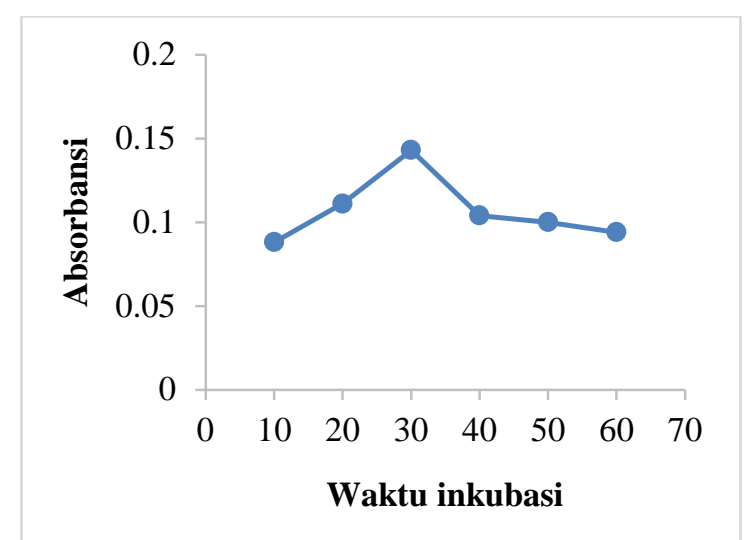

Gambar 7. Kurva Optimasi Waktu Inkubasi

sekunder yang memiliki kemampuan menangkap radikal bebas dan mencegah terjadinya reaksi berantai. Pengukuran ini menggunakan asam askorbat dalam beberapa tingkat konsentrasi untuk mendapatkan aktivitas antioksidan, yaitu kemampuan untuk dapat meredam radikal bebas dengan menggunakan metode DPPH yang kemudian ditetetapkan dalam kurva kalibrasi antara \%inhibisi terhadap konsentrasi vitamin $\mathrm{C}$ adalah $\mathrm{y}=7,9394 \mathrm{x}$ $+0,3521$ dan $R^{2}=0,9939$. Persamaan regresi linier tersebut digunakan untuk menentukan $\mathrm{IC}_{50}$ dari larutan vitamin $\mathrm{C}$.

Nilai $\mathrm{IC}_{50}$ adalah besarnya konsentrasi antioksidan untuk menghambat radikal bebas sebesar $50 \%$. Salah satu metode untuk menentukan nilai $\mathrm{IC}_{50}$ dengan peredaman radikal bebas DPPH. Hasil penelitian menunjukkan bahwa Vitamin $\mathrm{C}$ berpotensi aktif sebagai antioksidan dengan $\mathrm{IC}_{50}$ sebesar 6,253 ppm. Pada konsentrasi 5000 ppm ekstrak etanol $P$. australis menghambat sebesar $66,01 \%$ radikal bebas DPPH. Kemampuan menghambat yang lemah pada konsentrasi 5000 ppm menunjukkan rendahnya kekuatan antioksidan dari ekstrak etanol $P$. australis. Pereaksi DPPH bersifat stabil. Pada penelitian ini, pengurangan kemampuan mereduksi radikal DPPH ditentukan dengan penurunan absorbansi pada panjang gelombang $515 \mathrm{~nm}$ yang diinduksi oleh antioksidan (AH) setelah 30 menit, seperti reaksi dibawah ini (Brighente et al., 2007):

$\mathrm{DPPH}^{\circ}+\mathrm{AH} \longrightarrow \mathrm{DPPH}-\mathrm{H}+\mathrm{A}^{\circ}$

\section{KESIMPULAN}

Berdasarkan penelitian yang telah dilakukan, kadar fenolik ekstrak etanol rumput laut coklat adalah 42,62 $\mathrm{mg}$ SAG/g dan pada konsentrasi 5000 ppm menghambat sebesar $66,01 \%$ radikal bebas DPPH.

\section{DAFTAR PUSTAKA}

Bajpai, M, A. Mishra, D.A. Prakash. 2005. Antioxidant and free radical scavenging activities of some leafy vegetables. Int. J. Food Sci. Nutr. 2005. 56(7): 473-481.

Brand-Williams, W., M.E. Cuvelier, C. Berset. 1995. Use of a free-radical method to evaluate antioxidant activity. Food Sci Technol-Lebens Wissens Technol. 28: 25-30.

Brighente, I.M.C., M. Dias, L.G. Verdi, M.G. Pizzolatti. 2007. Antioxidant activity and total phenolic content of some Brazilian species. Pharmaceutical Biology. 45(2): 156-161.

Chow, S.T., W.W. Chaw, Y.C. Chung. 2003. Antioxidant activity and safety of $50 \%$ ethanolic red bean extract (Phaceolus raditus L. Var Aurea). Journal of Food Sciene. 68 (1): 21-25.

Dahuri, R. 1998. Coastal zone management in Indonesia: Issues and approaches. Journal of Coastal Development. 1(2): 97-112.

Depkes RI. 1979. Materia Medika Indonesia Jilid $V$. Direktorat. Jenderal Pengawasan Obat Dan Makanan. Jakarta.

Depkes RI. 2000. Parameter Standar Umum Ekstrak Tumbuhan Obat. Departemen Kesehatan Republik Indonesia. Jakarta 
Halliwell, B., J.M.C Gutteridge. 2000. Free Radical in Biology and Medicine.Ed 4th, Oxford University Press New York.

Haryani, T.S., B.L. Sari, T. Triastinurmiatiningsih. 2014.

Efektivitas ekstrak Padina australis sebagai antibakteri Escheria coli penyebab diare. Jurnal Ilmiah Fitofarmaka. 4(2):42-49. Universitas Pakuan. Bogor.

Hongayo, M.C., R.C. Larino, D.L. Malingin. 2012. Antibacterial and antioxidant effects of brown alga Padina australis Hauck crude extract. IAMURE International Journal of Science and Clinical Laboratory. 2(1): 1-5.

Kemenangan, F.R., G.D. Manu, F.B. Manginsela, $\quad$ F.B. 2017. Pertumbuhan alga coklat Padina australis di Perairan Pesisir Desa Serei, Kecamatan Likupang Barat, Kabupaten Minahasa Utara. Jurnal Ilmiah Platax. 5(2): 245-246.

Khoddami, A., M.A. Wilkes, T.H. Roberts. 2013. Techniques for analysis of plant phenolic compounds. Molecules. 18(2): 23282375.

Kim, D.K., K.W. Lee, H.J. Lee, C.Y Lee. 2002. Vitamin C equivalent antioxidant capacity (VCEAC) of phenolic phytochemicals. J. Agric. Food Chem. 50(13): 3713-3717.
Pelozo, M.I.G., M.L.C. Cardoso, J.C.P. Mello. 2008. Spectrophotometric determination of tannins and caffeine in preparations from Paullinia cupana var. sorbilis. Braz. Arch. Biol. Technol. 51: 447-451.

Peng, J.P. Yuan, C.F. Wu, J.H. Wang. 2011. Fucoxanthin, a marine carotenoid present in brown seaweeds and diatoms: Metabolism and bioactivities relevant to human health. Mar. Drugs 9(10):18061828.

Pelozo, M.I.G., M.L.C. Cardoso, J.C.P. Mello. 2008. Spectrophotometric determination of tannins and caffeine in preparations from Paullinia cupana var. sorbilis. Braz. Arch. Biol. Technol. 51, 447-451.

Proestos, C., D. Sereli, M. Komaitis. 2006. Determination of phenolic compounds in aromatic plants by RP-HPLC and GC- MS. Food Chemistry. 95(1): 44-52.

Valko, M., D. Leibfritz, J. Moncol, M.T.D. Cronin, M. Mazur, J. Telser. 2007. Free radicals and antioxidants in normal physiological function and human desease. The International Journal of Biochemistry \& Cell Biology. 39: 44-84

Winarsi, H. 2007. Antioksidan Alami dan Radikal Bebas. Yogyakarta 